\title{
Progress toward New Sentimental Educations: How Contextual and Constructivist Poetics Reframe Issues of Distribution
}

Vers de nouvelles éducations sentimentales: repenser la distribution à travers les poétiques contextuelles et constructivistes

El desarrollo de nuevas educaciones sentimentales: pensar de nuevo la noción de distribución a través de las poéticas contextuales y constructivistas

\section{Noura Wedell}

\section{OpenEdition}

Journals

Édition électronique

URL : https://journals.openedition.org/ideas/2009

DOI : 10.4000/ideas.2009

ISSN : 1950-5701

\section{Éditeur}

Institut des Amériques

\section{Référence électronique}

Noura Wedell, « Progress toward New Sentimental Educations: How Contextual and Constructivist Poetics Reframe Issues of Distribution », IdeAs [En ligne], 9 | 2017, mis en ligne le 13 juillet 2017, consulté le 20 octobre 2022. URL : http://journals.openedition.org/ideas/2009 ; DOI : https://doi.org/ 10.4000/ideas.2009

Ce document a été généré automatiquement le 20 octobre 2022

\section{cc)}

Creative Commons - Attribution - Pas d'Utilisation Commerciale - Pas de Modification 4.0 International - CC BY-NC-ND 4.0

https://creativecommons.org/licenses/by-nc-nd/4.0/ 


\section{Progress toward New Sentimental Educations: How Contextual and Constructivist Poetics Reframe Issues of Distribution}

Vers de nouvelles éducations sentimentales: repenser la distribution à travers les poétiques contextuelles et constructivistes

El desarrollo de nuevas educaciones sentimentales: pensar de nuevo la noción de distribución a través de las poéticas contextuales y constructivistas

Noura Wedell

\section{Contextual poetics and the relation to context}

1 Rather than examine questions concerning the distribution of avant-garde poetics within the social field of culture, this essay looks at texts that encapsulate the issue of distribution self-reflexively, in their very writing. Such texts, so-called constructivist or contextual poetics, provide a lens to reframe and map out another, internal version of the question of distribution ${ }^{1}$. The field of contextual poetics is composed of literary and artistic practices that disavow presuppositions of artistic autonomy and an unquestioned authorial voice. Its objects are predominantly composed through processes of collage, montage, and editing. Examples from art and literature range from the historical European and American avant-gardes (Russian constructivism, Dada, Futurism, American Objectivism in poetry, but also materialist poetics such as implemented by Francis Ponge in France, etc.), through the neo avant-gardes in literature (Tel Quel, American language poets) and in visual art (examples abound in conceptualism, and in its early form as a hybrid of art and writing, as published in the journal 0 To 9 for example) $)^{2}$. 
2 Constructivist and contextual poetics can be understood to provide an internal configuration of the issue of distribution. Such forms are constituted through their relation to context, and rely on context for their material production, through different techniques of sampling, montage, or détournement. But they are also intimately dependent on contexts of reception for their very constitution as objects. Indeed, since Duchamp, context is clearly a framing mechanism that is constitutive of the object, defining the object according to the different world or worlds that it inhabits ${ }^{3}$. In addition, the means of interpreting such forms also relies on histories and contexts of interpretation, contexts that have evolved parallel to the forms themselves, and that in turn contribute to what we could call their ontology (barring the essentialism of that term). Although distribution and contexts of reception are not isomorphic, the latter can perhaps be understood as idealized zones of distribution, or at least projected, phantasmatic, or desired zones of contact with a public that does not always materialize at will. In this sense, the difference between distribution and contexts of reception could be framed as a difference of actuality and virtuality. According to that view, distribution would provide the means for the actual interpretative framing enabled by specific readers at specific times, thus tracing a history of reception as the framing process is enacted in the different moments and spheres of its distribution, through the poetic grapevine, by small presses, bookstores, and through university curriculums. Contexts of reception, on the other hand, can be conceptualized as virtual frames, which determine the very existence of the object, and inaugurate a virtual history of framing as the unfolding of the possibilities of the work's interpretations and receptions. The question we ask in this text is what happens when the vagaries of framing not only determine the virtual existence of its object (as poetry, as text, as art, etc.), the different actualities of its reception, but are incorporated into the artistic process of production itself? What happens when these different instances of framing become the theoretical concern that the object intends to work through?

\section{Progress and its Reception}

The long poem by Barrett Watten entitled Progress proposes a form for such contextual reflexivity. First published in 1985 by New York's Root Books, the text, according to Watten, received a "jolting reception" upon its appearance4. The controversy had begun with a review of Watten's 1984 book Total Syntax by Tom Clark, a proponent of the Beats and longtime editor of the Paris Review. Clark took issue with Watten's use of language and had assessed the work as "the kind of mumbo jumbo you'd hear from a guy who stumbled into a linguistics lecture one day, and walked out an instant expert the next" (Clark T., 1985a). The turn of phrase was quite successful in its polarizing effect. Responses were published the following week. The first was by the poet David Melnick who called the review "a campaign of misinformation against Barrett Watten and the language poets" (Melnick D., 1985). The other was by the linguist who'd been teaching the course in question, George Lakoff. He found the review "outrageous, both in its stupidity and its malice" (Lakoff G., 1985). Not only did he call Clark out for using erroneous grammatical arguments, but he criticized him for being ignorant of contemporary poetry in general. Lakoff and Clark then published a new salve in Poetry Flash, a Bay Area newspaper providing poetry event listings and reviews, widely read in 
the poetry community, and not aligned with a particular sub-field (although fairly traditional). The title of Clark's piece, Stalin as Linguist, a quote taken from Watten's Progress, fueled many heated responses (Clark T., 1985b). A later review of Progress by Ron Silliman gave the tone of these when he described the book's reception as having occurred "with all the equanimity of an AIDS outbreak amid the Moral Majority (Silliman R., 1985: 12). 5 ." By labeling Progress a "contemporary poetic litmus test" in the title of his review, Silliman implied that Watten's production operated as a decisive factor in the poetic field, crystallizing the issues and polarizing the debates around language poetry itself. In broad strokes, these concerned the self-reflexivity of language use, the role of theory, the emphasis on doing rather than interpretation, and the situatedness of writing in its context ${ }^{6}$.

Progress was republished in 2005 by Green Integer press, along with another long poem entitled Under Erasure. The new volume was accompanied by a preface by Watten describing his writing process, examining the poetics of the two texts and recalling the reception of both texts in retrospect. In the section of the preface that concerns Progress, Watten describes the work as a culturally concerned modern epic, distanced from the subject-centered lyric, yet which nonetheless struggles through issues of "poetic voice." The scope of this voice is vaster, he claims, and not restricted to the bounds of subjective individuality as determined by social, economic, cultural and biopolitical structures; it concerns the process of constituting forms of subjectivity of all kinds, from individuals, to cultural groups, and social spaces. The very struggle of this poetic voice for coherence, movement, or progress figures the larger social yearning for political progress and subjective emancipation. The book centers on the problem of post-utopian politics, following upon the demise of the political euphoria and enthusiasm of the 1960s. It is fundamentally concerned with probing what occurs after the revolutionary impetus has crumbled, when spaces for social experimentation have dwindled, and the ruling ideology has destroyed, or incorporated, its ancient enemies. What happens at the wane of the great horizons of revolutionary promise, it asks. What alternative forms of subjectivity can still hold positive sway after alternative social experimentations have failed? How can the political underpinnings of avantgarde writing-understood as action on the symbolic realm through transformations in language use with claims to social effects-be justified in a context in which the balance of power has shifted back in favor of the most conservative agendas ${ }^{7}$ ? What is to be done with the failed hopes of revolution? How can enthusiasm and belief be rekindled in the face of overwhelming odds?

5 The republished Progress functions as an interesting case study due to the complexity of its contextual framings. A first series of frames, or readings, is provided by the text itself, its content-context composed through the reflexive process of its poetic voice through a hostile context. The next readings follow according to the contingency of distribution, each one contextualizing the text anew. The preface to the second edition furthers these framings, and launches the text upon another round of distribution. The preface functions as the text's double, its constructivist shadow, a settling on paper of one of the reflexive images which occurs when the text is read. It is a stabilized reading, and furthers the cascade of framings as it reflects upon what its author understands of the different possibilities of the "open reception" of interpretative indeterminacy that the text allows. 
6 One of its main issues is to probe the underside of Duchamp's confident gesture of contextual inscription. Indeed, although he meant to test it, Duchamp did rely upon the basic premise of the Society of Independent Artists' open and democratic exhibition policy (pending a small fee, of course). More generally, his gesture partook of a belief in esthetic progress that would transform not only arts institutions, but the larger audience engaging with the space of culture. The context for the writing of Progress was radically different. Progress was written in Oakland, between 1982 and 1983, at the tail end of the Reagan recession, in what Watten described as "a period of social and political retrenchment, the overturning during the Reagan Era of whatever was left of the utopian imaginings of the 1960 s and even more, of the prior cultural politics they intended to preserve but ended up destroying." (Watten B., 1985: 7-8) Not only did this reflect upon the social and political context of neoliberalism, but the more painful internal critique concerned the actual effects of emancipatory cultural politics as well as the cultural logics of late capitalism. Indeed, in the early 1980s, what Boltanski and Chiapello have called the new spirit of capitalism, with its incorporation of artist's critique, was thriving in the digital revolution that swept Silicon Valley. In the cultural sphere, debates around postmodernism, transformations in the media and in technology, and ideas of self-reflexivity foregrounded the feedback loop between economic and cultural structures.

7 Such were the contexts of reception available to Progress, hostile on both fronts. The text had to contend not only with a quite limited, and very polarized, reception in the dwindling cultural site of high-culture, but also with a general ideological hostility from within the cultural field and outside of it. As Watten clarified in his preface, the text responded to the lack of political horizons in a negative way. It constructed a poetic voice, made unsteady by its unease in regards to its context and to its own participation in that context. This was given in the fragmentary form through which the poem's discursive reflexivity and thematic unfolding progressed.

\section{Writing in a hostile context}

8 The text is made up of discrete borrowings from the diverse contexts of sociocultural life at the time, pausing and starting again in a recombinant order. It borrows from scientific discourse, with such self-reflexive fragments as "I want to solve an equation" (Watten B., 2004: 43) for example, or "Repeats the white of the sum. ..." (46), "Keep particles under attack." (47), or "Berkeley's/Invention of element 103,/Not yet Berkelium because/I have not given it a name. ..." (103). There are references to an order of fact, with mention of historical figures (Trotsky, Kennedy, Nixon), places (Vietnam, South Africa, Morocco), things and events. But the text also plays with this, through several reflections on the very idea of fact ("A fact demanding visualization" (153), "A fact is not narrative/But a positive impression/of fact." (86)). The specific history and context of aesthetic production is represented by intertextual references to the history of literature and art (the invocation of the camera, or music, for example). There are also more philosophically inflected reflections on poetics, esthetics and language. We find issues concerning subjectivity, voice, an "I," a "you," and the subjective construction of meaning. Economic considerations on production and capital are also threaded through the text, for example in "An extraction of surplus value/ 
Raised anywhere is,/labor/But identical to product/So that I and my ideas will win. ..." (89) or through more historical markers such as "Workers in Ohio,/defeated" (99).

9 The text, according to Watten in hindsight, "proposed an unfolding of synthetic discourse as if in an empty space that might be given the name 'culture' but that the poem rejects" (6). Watten's understanding of the emptiness of culture is perhaps both a refusal and an avowal of possibility. In the context of contextual poetics, the emptiness of culture might refer to its expanded field, no longer separated from the larger social field by clear cut distinctions about style, content, or target audience. In this sense, the restrictions around culture should be rejected by any self-respecting avant-garde. But this emptiness might also be a statement about the parataxic use of language, a Buddhist inflected account of the infinity inherent in the endlessness of parts and their capacity for assemblage: "Like/Language, any part is endless. ..." (45).

As for culture, in 1973, it seemed that the sphere of action for revolutionary cultural organization was severely restricted, if not foreclosed. At the height of the postmodern, Watten seemed shut off from any meaningful reaction to the economic structures underlying the cultural. One effect of this was the foreclosure of the sense of historical development inscribed in the term culture itself 8 .

The struggle, then, of the book Progress, is to come to terms with the reversal of its own conditions of possibility. In a moment of economic recession, cultural restriction, and a generalized enmeshing of culture in capitalism, Watten reacts through rejection. For him, the poem determines its context by aversion, arguing its place in the order of culture by negative means. Its progress is to undermine any fixed context it may have, building its internal coherence by a multiplicity of broken contextualizing threads that nonetheless coalesce as the reading progresses. As it moves, however, a looseness of definition and assemblage settles into an affect, or a tone, which differs with each reading and with the emphasis of the reader's eye and mind. At the moment of this writing, the melancholy tone of this text strikes a chord in what seems like an even worse political landscape under the presidency of Donald Trump.

How does the text itself work through these issues? As we have seen, the composition of Progress is based on thematic threads progressing through the poem as the trembling, unstable shape of a voice. This voice is the text itself, in progress, but also a "you," both "I" and "you" constituted where sense can start to coalesce as the site of culture. The voice charts a motion through time, a path towards an end that is given in the structure of the book itself. This (un)making sense is constructed and problematized by several methods.

13 The first method of progress is parataxis. The contradictory production of meaning progresses through syntactic breaks and starts, which function either to fracture meaning, or to develop it, although with surprising twists, from one line to the next, and across stanzas. More or less explicit references are bracketed by statements that make sense in an expanded way, or only obscurely. As it progresses, however, the text weaves these disparate senses in ways that cohere, even if the reader must sometimes grasp at meanings like phantoms. Take the following selection:

In a St. Vitus dance.

Exploded

Rhetoric of separate parts

Shifts in rapid succession,

Landscape moves by at a rate. ... (126) 

succession") are personified through the allusion to illness (the St. Vitus dance). But the final line, although repeating the sense of rapid succession, also grounds these poetics into a sensing subject who might be witness to the passage of the snippets of verse like a rapidly moving landscape seen from a train. Or take this section here:

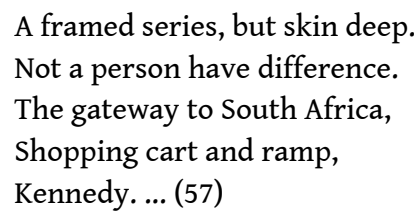
difference, but their meaning remains indeterminate and hazy. They can also be read as self-reflexive poetic remarks, which are also reflections on subjectivity. Then echoes of apartheid South Africa, of consumer society, and of American cold war politicians allude to the politics of race, class and difference. But they are also frames for a stumbling "I".

For in fact, the text progresses through a mix of semantic abstraction and concreteness. Take, for example "The literary potential in/A $99 \$$ pen./To make a present. ..." (159). Here, several different threads cohere. In terms of the text's meaning, there is of course a reference to the materialist reading of culture, showing the inevitability of economic inscription since the pen has a specific price, an economic reality which will inflect culture. In the phrase I can also infer a democratic impetus for the production of that culture, because it's a cheap pen after all. I also hear echoes of gift economies in "making a present." This background of associations is significant, yet all of these associations remain indeterminate and open versus the definite read of the more literal sense: it is the material pen that is being used to produce culture, writing the text itself This indexical method, heir to the objectivist and literal traditions, foregrounds presentness and materiality as set modalities of sense making. The material, here, would seem the concrete condition for progress. Perhaps I can step forward on it.

But that is not so sure. The gesture is indexical in the present of writing, but then joins the web of meanings once readings start. What remains is the complexity of the play of language, layers of indexes, symbols, and multiple referential orders. Adding to this layering effect, the indexical method can be read as a second order reflection on writing, addressing its conditions of production. And this can be manipulated, because writing contains the possibility of ordering the index. "Here I am altering order/Of index to present time/In order to be more immediate. ..." (122). The material, which might have served to ground the requirements of trust and truth, becomes irremediably intertwined with the changeable interpretability of language and of politics.

Figure. State is severed from

States of affairs? You

speak for themselves,

Materials,

the voice comes out. ... (24) 


\section{Strategies against involuntary recognitions}

Despite its uncertainty, the progress of this unstable composite gestures nonetheless towards a horizon of transformation. It is as minimal as making sense, as maximal as social upheaval. Its promise has something to do with the proliferation and acknowledgment of difference, where singularities can be affirmed through their distinctive differential qualities. Read positively, the text's jumble of meaning allows a voice to grow, sidestepping subjection to confining norms, and engaging instead with the unknown, the incomplete, the undescribed, the obscure or the negative. We can thus understand negativity as a fundamental openness, an escape from definition, a field of potential'. The forms such negative processes, or "contradictory productions" (131) of subjectivity might take are numerous.

One of these is symbolized by the widely circulated theory in radical formalist poetics of the indetermination of interpretation. Disruptions in language use, through parataxis or the new sentence, are meant to operate against the unquestioned orders of the symbolic. The way a subject constructs sense is thus both a decomposing of existing norms as well as the production of an experimental process. The newly emancipated reader thus supposedly occupies the site of production, instead of what had previously been deemed a passive state of consumption ${ }^{10}$. Progress explores the possibility of this indetermination of interpretation as the tenuous, awkward, mutable story of an "I" as it is solidified and rendered immobile by a specific instance of a "you," named in the text and differently materialized in its renewed interpretants.

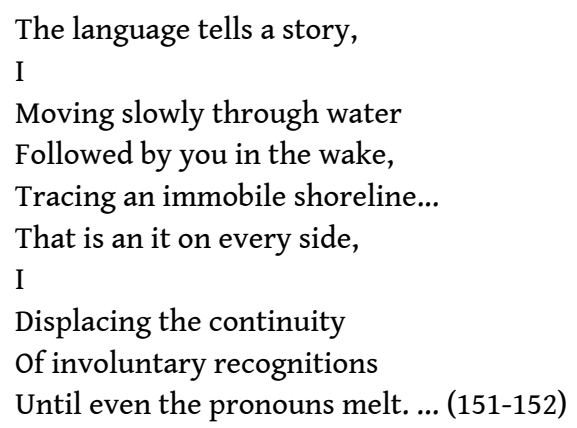

Watten addresses the issue of interpretative indeterminacy in his preface, explaining that it fails in two important ways, thus defaulting on its emancipatory promises. First, because the reader never does make meaning purely out of the openness of the text, and second, because poetic autonomy never existed, so that readings are always made in relation to a culture at large ${ }^{11}$. The temporary immobility of the shoreline of the I/ you composite only displaces habitual, confined and more or less alienated recognitions of self imposed by social constraints. The mobile cultural context of involuntary recognition does not deliver emancipation, nor does the overturning of poetic structures lead to its promised liberative effects. What new readings might be made of the text merely add layers upon the cultural data which preexist them, without engaging fundamental change. Autonomy was never the case in the first place. Everything is determined by its context. Progress, given over to the historicity of its interpretative frames which do nothing but repeat the endless drone of confinement, is thus fundamentally uncertain. 
21 Let us look more closely at the evolution of the I-you graph as an image of subjectivation practices. There is, it is written, a "constant production of self" in the unavoidable shifting or movement of that sea and its shore.

Chess pieces on a spiral board

Tilted into waves.

Freight

Backwards, veil behind veil,

Constant production of self. ...

In its extremes is unintended. (76)

The shifters of such movements wear hats, that is, the I/you pair of indexical signs are defined by their contextual inscription ("shifters/ Wear their hats (shifters)") (78). Indeed, hats repeatedly reappear during the length of the text, to point to both symbolic and indexical use. We thus find a blend of both registers, symbolically hinting, for example, towards political inclinations, committed language use ("On the obsolete dictionary / I put the red hat. " (69)), or defense against the chilling exposure of spectacle ("In winter I wear a hat, / To guard against witnesses." (17)), all the while maintaining their indexical aspect (the red cover of Webster's dictionary, the intensity of winter's temperature shifts). Such a proliferation of hats or frames point to the multiple language games through which Watten's text progresses. The I/you shoreline is thus also built into the sorting game of poetics as it exists within its context of capitalist individualism: "Sorted as an individual... / I am responsible for product.../ You to give back response" (149-150). Individuality, production, consumption, response: avant-garde poetics provide no out. As we have seen, even its impersonal it cannot provide for escape from such fixed games of usage through which subjects try to make sense of their worlds, building representation strategies that are also leverages for power.

The revolutionary trappings of the avant-garde are of no help here. Neither are the emancipatory hopes of revolutionary community that have definitely waned in postutopian 1982. The literalist utopia of objectivist poetics, in which the index enables a meeting of the territory with the map, feel too rigidly materialist, as well as somewhat essentialist, for it misses the groundlessness of the material itself. Presentism seems undermined by a certain order of economy, a gradation of the value of presence in time. Indeed, if there is a structural need for innovation in neoliberalism, as Frederick Jameson (1991) argues, then the present is reduced to a moment in a race towards endless and harried productivism. Finally, the possibilities inherent in the radical indeterminacy of interpretation are negated by the closure of the progress of reading. "Theme of the end of closure.../Interpreted/ends in new sleep." (159). The quandary is that economic relations subtend the entire project: writing, and its correlate, reading, imply a relation of consumption, literature circulates value. The originality of metaphor is nothing but the debt to be paid back in the construction of future regimes of legibility that shall be their return on investment. ("It is an original, meaning that value can take out a loan/to pay for time in advance/so anyone can process words." (160)) "This is an irritable art" (175) indeed, where the sharing, the building of meaning that might occur through the process of reading, in which the I becomes the you, is reduced to nothing but stops, habits, points, and the 'you' is restricted to the deciphering of closed meaning. The utopian impetus can go no farther than positing the poetic act as expropriating private property for public use. It does not undo the economic structuring of the self as private property ${ }^{12}$. 

culled the link between shifters and hats, when restored, is the following: "In occluded buildings, / shifters/ Wear their hats (shifters)/To put a space in between. / Frame is the syntax of what..." (78). This unknown "what" is the text's horizon of progress, a space in between, a gap against forced or involuntary recognition, leading to a second order logic through which we might see out. That is the negative horizon of Progress: "The better life that Progress proposes can be known only in the negative, as a form of reversal, a turning inside out or away from a total annihilation that yields-the horizon of an act whose context has yet to be determined." (11).

At the end of Progress, we are thus left us with very few certainties. There is an open ended "what" referring to a context that is as yet undetermined, or perhaps some sort of mysterious act. Once Duchamp's contextual gamble has lost its edge, and there is nothing to be gained by contextual shifts, the question returns to the self, and what it might mean to organize one's own freedom from constraints. To this end, the work proposes an objective form of the $I$, a map that closes on the lines:

Excite I a map of my position

By means of lines,

adding

The date to a list of days,

With astronomical slowness... (221).

In view of these lines, we can interpret Watten's project as attempting an intensification of subjectivity. In that sense "Excite I," is a way to reject a negative context while spreading open subjective possibilities. This new open map of the self is meant to continue its process of intensification of subjective zones. It is meant to be circulated. It assumes the cold fact is that there is no other order of emancipation, no utopian outside or nonself, but only intensities of selfhood to be practiced against involuntary recognition ${ }^{13}$. All signs point to distinctions of power, say Deleuze and Guattari, following Spinoza's critique of signs. Indeed, for Spinoza, signs often lead us to take a principle of obedience for a model of knowledge. "[...] one only has to misunderstand an eternal truth, i.e. a composition of relations, in order to interpret it as an imperative." (Deleuze G., 1988) That is why it is necessary to lay out a map of the contexts in which signs emerge. "Signs require first of all a pragmatics, the exposure of the relations of domination in which they are inscribed, that they serve and to the strengthening of which they often contribute." ${ }^{14}$ If we cannot access the true composition of relations, a pragmatics of signs affords a way to relate to the unknown without enforcing obedience to preexisting forms. But in a hostile context, it is increasingly difficult to read this pragmatics of signs, especially under the regime of spectacle, where visibility is dangerous due to capitalism's powers of recuperation. By engaging with context through negativity, Watten strategizes a resistance to the visible and to the clearly legible. His text is written following the disappointment of labor struggles in the industrialized countries, in a moment which sees the rise of dictatorships and neocolonialist regimes following upon the heels of the movements for national liberation in the global south. It is witness to the rapid spread of neoliberal economic policies via globalization, the heightening of negative mythologies of fear, sky wars nightmares, narratives of ecological disaster, economic depression and defensive individualism. It can no longer believe in the self-serving mythologies of progress in culture, so clearly is culture implicated in the pillage and servitude of globalized capitalism. In response, Watten's Progress, as a serious attempt at making 
sense of our place in the world-"Then I mean I mean," (32)-demands that we review our own identifications. What it can provide is the emptiness to do so, what it calls poetry. "The poetry is this distance/Given in place of names." (101).

\section{BIBLIOGRAPHIE}

Altieri, Charles, "Without Consequences is no Politics: A Response to Jerome McGann", in Robert von Hallberg (ed), Politics and Poetic Value, Chicago, Ill., Chicago University Press, 1987.

Andrews, Bruce and Bernstein, Charles (eds.), The $L=A=N=G=U=A=G=E$ Book: Poetics of the New, Carbondale and Edwardsville, Ill., Southern Illinois University Press, 1984.

Bartlett, Lee, "What Is" Language Poetry" ?", Critical Inquiry 12, nº 4, Summer, 1986, p. 741-752.

Benson, Steve, Harryman, Carla, Hejinian, Lyn, Perelman, Bob, Silliman, Ron, and Watten, Barrett, "Aesthetic Tendency and the Politics of Poetry: A Manifesto", Social Text, No. 19/20 (Autumn, 1988), p. 261-275.

Bernstein, Charles, "Characterization", in Writing/Talks, Bob Perelman (ed.), Carbondale and Edwardsville, Ill., Southern Illinois UP, 1985.

Burton-Jones, Alan, Knowledge Capitalism: Business, Work and Learning in the New Economy, Oxford, Oxford University Press, 2000.

Cantwell, Jacqueline, Rodefer, Stephen, and Silliman, Ron, "Flashback. Re: David Levi Strauss' On Duncan \& Zukofsky On Film, \# 135, June 1984", Poetry Flash \# 136, July 1984.

Clark, Tom, "Review: Total Syntax", San Francisco Chronicle, January 13, 1985.

Clark, Tom, "Stalin as Linguist", Poetry Flash, July 1985, p. 5 and 11.

Clark, Tom, "Stalin as Linguist", Partisan Review, Spring 1987, p. 289-304.

Clark, Tom, The Poetry Beat: Reviewing the Eighties, Ann Arbor, Mich., University of Michigan Press, 1990, p. 65-83.

Davidson, Michael, "Skewed by Design: From Act to Speech Act in Language Writing", Fragmente 2 (Autumn 1990).

Deleuze, Gilles, Spinoza Pratical Philosophy, transl. Robert Hurley [orig. ed. Spinoza Philosophie Pratique, Paris, Minuit] San Francisco: City Lights Books, 1988 [1970], 106.

Epstein, Andrew, "Verse vs. Verse: The Language Poets are Taking Over the Academy. But Will Success Spoil Their Integrity?", Lingua Franca, Sept. 2000, p. 45-54.

Hague, Douglas, The Knowledge-Based Economy, Oxford, Templeton College, 1994.

Hartley, George, Textual Politics and the Language Poets, Bloomington, Ind., Indiana University Press, 1989.

Hickman, Ben, "Figures of inward: Language poetry and the end of the avant-garde", Crisis and the US Avant-Garde: Poetry and Real Politics, Edinburgh, Edinburgh University Press, 2015, p. 140-159. 
Jameson, Frederick, Postmodernism, or, The Cultural Logic of Late Capitalism, Durham, N.C., Duke University Press, 1991.

Jerome McGann, "Response to Charles Altieri", in Robert von Hallberg (ed), Politics and Poetic Value, Chicago, Ill., Chicago University Press, 1987.

Kim, Eleana, "The New Americans vs. the Treed Americans", Language Poetry: Dissident Practices and the Makings of a Movement. Available online : http://home.jps.net/ nada/language6.htm. Accessed May 2, 2017.

Lakoff, George "Letters to Review: Total Syntax", San Francisco Chronicle, January 27, 1985, p. 11. Lazer, Hank, Opposing Poetries, Volume One: Issues \& Institutions and Volume Two: Readings, Evanston, Ill., Northwestern University Press, 1996.

Lazzarato, Mauricio, Les Révolutions du Capitalisme, Paris, Les Empêcheurs de Penser en Rond, 2004.

Levi Strauss, David "On Duncan and Zukovsky on Film", Poetry Flash, nº 135, June 1984.

McGann, Jerome "Response to Charles Altieri," in Robert von Hallberg (ed), Politics and Poetic Value, Chicago, Ill., Chicago University Press, 1987.

McGann, Jerome, Social Values and Poetic Acts: a Historical Judgment of Literary Work, Cambridge, Mass., Harvard University Press, 1988.

Melnick, David "Letters to Review: Total Syntax", San Francisco Chronicle, January 27, 1985, p. 11.

Mortley, Raoul, From Word to Silence, 2 vols., Bonn: Hanstein, 1986.

Moulier-Boutang, Yann, Cognitive Capitalism, transl. Ed Emery, Cambridge, UK, Polity Press, 2011.

Perelman Bob (ed.), Writing/Talks, Carbondale, Ill., Southern Illinois UP, 1985.

Perelman, Bob, The Marginalization of Poetry: Language Writing and Literary History, Princeton, N.J., Princeton University Press, 1996.

Perloff, Marjorie, "The Word as Such: $\mathrm{L}=\mathrm{A}=\mathrm{N}=\mathrm{G}=\mathrm{U}=\mathrm{A}=\mathrm{G}=\mathrm{E}$ poetry in the eighties", The Dance of the Intellect: Studies in the Poetry of the Pound Tradition, Chicago, Ill., Northwestern University Press, 1996.

Reinfield, Linda, Language Poetry: Writing as Rescue, Baton Rouge, La., Louisiana State University Press, 1992.

Sauvagnargues, Anne, Deleuze et l'art, Paris: PUF, 2005.

Silliman, Ron, "A Contemporary Litmus Test: Progress by Barrett Watten", San Francisco Chronicle, Nov. 17, 1985, p. 12.

Situationist International Anthology, Knabb, Ken (ed.), transl. Nadine Bloch and Joel Cornuault, Berkeley, Calif., Bureau of Public Secrets, 1981.

Thrift, Nigel, Knowing Capitalism, London, Thousand Oaks, New Dehli, Sage Publications, 2005.

Tiqqun, " Thèses sur la communauté terrible ", Tiqqun, no. 2, Octobre 2001.

Toffer, Alvin, The Third Wave, New York, N.Y., Bantam Books, 1980.

von Hallberg, Robert (ed), Politics and Poetic Value, Chicago, Ill., Chicago University Press, 1987.

Watten, Barrett, The Constructivist Moment: From Material Text to Cultural Poetics, Middletown, Conn., Wesleyan University Press, 2003. 
Watten, Barrett, Progress/Under Erasure, New York, N.Y., Roof Books, 1985.

Watten, Barrett, Progress/Under Erasure, Los Angeles, Green Integer Press, 2004.

Watten, Barrett, Questions of Poetics: Language Writing and Consequences, Iowa City, Iowa, University of Iowa Press, 2016.

Williams, Raymond, Keywords, Rev. Ed., New York, N.Y., Oxford University Press, 1983.

\section{NOTES}

1. "Constructivist poetics" is a term borrowed from Barrett Watten. It brings together both the constructedness of the poetic object and the construction of its interpretive apparatus (Watten B., 2003).

2. O TO 9 was a journal edited by Vito Acconci and Bernadette Mayer that ran from 1967 to 1969 . It showcased a number of artist (Robert Smithson, Adrienne Piper, Sol LeWitt, Douglas Heubler), dancers (Steve Paxton, Yvonne Rainer), musicians (Morton Feldman) alongside poets (contemporary and historical, among which were Aram Saroyan, Ron Padgett, Clark Coolidge, Hannah Weiner, but also Gertrude Stein, Raymond Queneau, Novalis), and texts from indigenous sources.

3. Howard Becker proposes the term "art worlds" to refer to the cooperative network of persons involved in the production of artwork, from the artists or writers, to editors, translators, suppliers, performers, dealers, critics, and consumers. The social production of artworks has been analyzed by Raymonde Moulin, Pierre Bourdieu, and Natalie Heinich, among others.

4. For an analysis of the agonistic context of the reception of early Language poetry in San Francisco, and in particular a talk by Barrett Watten on Zukovsky on December 8, 1978 at the San Francisco Art Institute that was violently interrupted by Robert Duncan, see Kim E., 2017. See also David Levi Strauss's account of the evening (Levi Strauss D., 1984) and divergent responses by Ron Silliman, Jacqueline Cantwell and Stephen Rodefer (Cantwell J., 1984).

5. For Tom Clark's take on the controversy, see Clark T., 1987 and 1990.

6. For an overview of these debates, see for example Perloff M., 1996; McGann J., 1988; Bartlett L., 1986; Perelman B., 1996; Lazer H., 1996; Hartley G., 1989; and Reinfield L., 1992.

7. There has been considerable debate around the political claims of language poetry. Some of the issues relate to the cultural logics of late capitalism generally, and to the relevance and efficacy of avant-garde political claims. The debate involves institutional questions, in particular the relation to the academy with the hiring of a number of language poets to academic positions. It also concerns their use of language, sometimes deemed anti-democratic, either because of an aversion to theory on the part of the critic, or to the shift away from the vernacular lyric of the Williams' tradition. On the inclusion of language poets into the academy and the question of high theory, see Epstein A., 2000. On the relation to political struggle, see Hickman B., 2015; Watten B., 2016. The bibliography concerning postmodernism and the implication of culture and neoliberalism is too vast for this entry. It ranges from sociology (from the Frankfurt school through Chiapello and Boltanski, or Latour), philosophy (borrowing from Nietzsche and Heidegger, and including poststructuralists such as Foucault, Deleuze, Lyotard, Baudrillard, and Derrida), political theory (Jameson, Harvey), to aesthetics (Andreas Huyssens, Benjamin Buchloh and writers of the October journal).

8. See Williams R., 1983: 90-91.

9. The tradition of the via negativa has a long history in both Western and Eastern theology. It refers to the removal of the attributes of God until the divine is revealed in itself. In the Western canon, the idea originates in later Platonism, spreads in Gnostic texts and early Christian writers. 
Kierkegaard is a 20th century proponent. In Hinduism, writers such as Shankara elaborated forms of apophatic thinking in the Advaita Vedanta school of philosophy and numerous forms of Buddhism have theorized and practiced the via negativa as well. In the arts, where the revelation of God is less at issue than the erasing of attributes from secular matters, we could cite the tradition extending from Duchamp through Vito Acconci and Mladen Stilinovic, or Snejanka Miyalova today, and for poetry, T.S. Eliot, Celan or Montale. For a Western history of the concept, see Mortley R., 1986.

10. On the role of the reader, see Andrews B. and Bernstein C., 1984, and in particular Jed Rasula's essay "Statement on Reading in Writing." See also Bernstein C., "Characterization," Writing/Talks, in Perelman B., 1985; Davidson M., 1990; Altieri C., 1987; and McGann J., 1987. In relation to cognitive capitalism, the role of the reader can be considered parallel to that of the prosumer, $a$ term coined by writer and futurist Toffer A., 1980. Among the voluminous literature on cognitive capitalism, see for example Moulier-Boutang Y., 2011; Lazzarato M., 2004; Thrift N., 2005; Hague D., 1994; Burton-Jones A., 2000.

11. "[... ] what is this universal openness of possibility but a play of the imagination that is the enabling mode of cognition for any work of art? It would be hard to find much in the order of culture that does not base its effects on some kind of openness of interpretation, even while immediately subsuming it in the work that culture is understood to perform all along. Such an end would be the necessity of the beleaguered percipient coming to terms with an encompassing meaning that is in no sense, ever, specified by the work; rather, the culture at large determines it. It is not, then, simply that poetic autonomy is the hallmark of a confining cultural discourseand its overturning, therefore, the emancipation of the reader. Poetic autonomy never existed, except as an index to the larger, more inchoate, order it is contained within." (Watten B., 2004: 9) 12. "Here is private property, to be Expropriated for public use." (Watten B., 2004: 168).

13. "This is often what the use of the I in our work has involved-to propose, in the inherent terms of the work, that sense of a connection between discrete conceptions which has been habitually effaced from the processes of thought and language and to recharge this neurological scar tissue with some new synapses." (Benson S. et al., 1988)

14. See on this issue the chapter "Critique et Clinique," in Anne Sauvagnargues A., 2005, especially p. 54-58, as well as the entry "Sign," in Deleuze G., 1988: 105-107.

\section{RÉSUMÉS}

Cet article s'intéresse aux liens du poème de Barrett Watten, Progress, à son public ainsi qu'à ses contextes économique, politique et socioculturel. Le poème, écrit en 1982-83 à la fin de la récession des années Reagan, est une réflexion sur la production culturelle dans un contexte néolibéral hostile, suite aux échecs relatifs des mouvements d'émancipation des années 1960 et 1970, et au sein du démantèlement de l'horizon de progrès promis par les formes esthétiques d'avant-garde. Le texte de Watten est construit de manière paratactique à partir de samples des divers contextes ou mondes qu'habite son auteur. Le texte compose une voix dont l'instabilité reflète l'expérience de la culture dans un contexte où le rôle politique de l'art est compromis. Cette voix se construit de manière négative, à l'encontre des récits linéaires et des interprétations stables. Par son refus du visible et du clairement lisible, le poème instaure une relation stratégique à son contexte. Watten propose ainsi un espace culturel vide qui nous incite à revoir nos manières d'habiter nos mondes et de nous y reconnaître. 
This article looks at how Barrett Watten's poem Progress relates to its audience, and to its sociocultural, economic and political contexts. Written in 1982-83 at the tail end of the Reagan recession, the poem is a long reflection on what it means to produce culture in a hostile neoliberal context, following the relative failure of the emancipatory movements of the $60 \mathrm{~s}$ and 70s, and the dismantling of the horizon of progress of esthetic forms themselves. Watten's poem is written in a parataxic mode via samplings of the contexts or worlds that its author inhabits. The text constructing an unstable voice that reflects the experience at the site of culture once the political role of art has been compromised. This voice builds itself up through negativity, by refusing linear narratives and stabilized readings, strategizing its relation to its context by resisting the visible and the clearly legible. Watten thus proposes an empty site of culture through which we might rethink how we inhabit our different worlds and recognize ourselves there.

Este artículo se interesa por las relaciones entre el poema de Barrett Watten, Progress, y su público así como por una contextualización económica, política y sociocultural. El poema, escrito en 1982-83 a finales de la recesión del periodo Reagan, es una reflexión sobre la producción cultural en un contexto neoliberal hostil, tras los fracasos relativos de los movimientos de emancipación de los años 1960 y 1970, y con el trasfondo del desmantelamiento del horizonte de progreso prometido por las formas estéticas de la vanguardia. El texto de Watten se construye de forma paratáctica a partir de samples de diversos contextos o mundos en los que habita el autor. El texto compone una voz cuya inestabilidad refleja la experiencia de la cultura en un contexto en el que el papel político del arte está comprometido. Dicha voz se construye de manera negativa, en contra de los relatos lineales y de las interpretaciones estables. Por su rechazo de lo visible y de lo claramente legible, el poema instaura una relación estratégica con su contexto. Watten propone así un espacio cultural vacío que nos incita a enfocar de nuevo nuestras maneras de habitar nuestros mundos y de reconocernos en ellos.

\section{INDEX}

Keywords : contextual poetics, Barrett Watten, neoliberalism, via negativa, culture, emancipation, experience

Palabras claves : poéticas contextuales, Barrett Watten, neoliberalismo, via negativa, cultura, emancipación, experiencia

Mots-clés : poétiques contextuelles, Barrett Watten, néolibéralisme, via negativa, culture, émancipation, expérience

\section{AUTEUR}

\section{NOURA WEDELL}

Noura Wedell is a writer, scholar, translator, an editor for Semiotext(e). Her research centers on contemporary writing and visual art with a focus on questions surrounding language, materiality and politics. She had edited a book on writing in the work of Robert Morris (Investigations: the Expanded Field of Writing in the Works of Robert Morris), and has translated six books, among which are theoretical texts by Toni Negri and Guy Hocquenguem, and two autobiographical narratives by Pierre Guyotat. Her book of poetry, Odd Directions, replays 1970s conceptualist investigations of space and meaning. She is a lecturer in Critical Studies at the Roski School of Art and Design at USC, Los Angeles. 